\title{
$\beta$-Galactosidase Synthesis in Klebsiella aerogenes Growing in Continuous Culture
}

\author{
By R. W. SMITH AND A. C. R. DEAN \\ Physical Chemistry Laboratory, University of Oxford, Oxford, $O X$ I $3 Q Z$
}

(Accepted for publication 13 March 1972)

\begin{abstract}
SUMMARY
Highest levels of $\beta$-galactosidase specific activity found after protracted growth of Klebsiella aerogenes (syn. Aerobacter aerogenes) in lactose-limited chemostat culture were only developed with cultures previously conditioned to lactose in batch culture. The hyperactivities were not induced further by methyl thiogalactoside (MTG) and depended on dilution rate, being maximal at $D=0.25 \mathrm{~h}^{-1}$. They were associated with increased substrate transport and utilization and, apart from a transient disturbance, were not affected by addition of glucose, galactose or glucose-6-phosphate to the lactose-limiting medium. Maltose addition produced a greater transient effect than the substances above, while citrate, $\alpha$-methyl glucoside and 2-deoxyglucose were inactive. Before hyperactivity developed, adding glucose led to a rapid decline and adding MTG led to a rapid increase in $\beta$-galactosidase activity. Methyl thiogalactoside exerted an inhibiting action at only the final stage, the bacterial yield being decreased, and its continued presence enabled glucose-adapted organisms to utilize glucose and lactose simultaneously. The lactose was utilized in two stages. $\alpha$-Galactosidase hyperactivity occurred after protracted growth in melibiose-limited conditions, but $\beta$-glucosidase hyperactivity did not develop in cellobiose-limited medium.
\end{abstract}

\section{INTRODUCTION}

Most investigations of the properties of $\beta$-galactosidase and the mechanism of its regulation have referred to the enzyme in strains of Escherichia coli (e.g. Monod \& Cohn, 1952; Herzenberg, I959; Jacob \& Monod, I96I ; Pardee \& Prestidge, I96I), often using 'gratuitous' induction of the enzyme by non-metabolizable inducers, such as methyl- $\beta$ D-thiogalactoside (MTG) or isopropyl- $\beta$-D-thiogalactoside (IPTG). Although such inducers simplify the kinetics of induction (Monod \& Cohn, 1952) they represent an artificial state of metabolism, particularly as possible feedback effects of metabolic products of the inducing galactoside will not be observed.

In these studies lactose, the 'natural' inducer, was used to induce $\beta$-galactosidase in Klebsiella aerogenes grown in continuous culture in a turbidostat and in various nutrientlimited chemostats so that steady states of activity could be obtained in a range of constant environments. Richards \& Hinshelwood (1961, 1962) and Richards (1969) have investigated $\beta$-galactosidase synthesis in batch cultures of the same strain of $K$. aerogenes and to a limited extent in turbidostat culture, the latter technique being mainly used to study the effects of changing the $\mathrm{pH}$ or the oxygen content of the medium, while Strange (1961) has examined the induction of the enzyme in conditions in which the bacteria utilize their amino acid reserves. 


\section{METHODS}

Organism and culture. Klebsiella aerogenes NCIB $4 \mathrm{I} 8$ fully adapted to a minimal medium containing the appropriate carbon source (see later) was grown at $40^{\circ} \mathrm{C}$ and a $\mathrm{pH}$ maintained at $7 \cdot 1 \pm 0.05$ by a Pye autotitrator. The continuous culture apparatus and the general techniques were described by Dean \& Rogers (I967). At the low population densitities used (p. 40) the addition of anti-foaming agents was unnecessary. Oxygen tensions, measured with a Mackareth electrode, were maintained at values considerably in excess of $15 \mathrm{~mm}$ $\mathrm{Hg}$, by passing air at I $1 / \mathrm{min}$ through the $300 \mathrm{ml}$ culture. Harrison \& Pirt (I965) considered tensions above $15 \mathrm{~mm} \mathrm{Hg}$ adequate for balanced aerobic growth of $K$. aerogenes.

Media. The standard minimal medium contained $(\mathrm{g} / \mathrm{l}): \mathrm{FeSO}_{4} \cdot 7 \mathrm{H}_{2} \mathrm{O}, 0.2 \times \mathrm{IO}^{-3} ; \mathrm{MgSO}_{4}$. ${ }_{7} \mathrm{H}_{2} \mathrm{O}, 0.039 ;\left(\mathrm{NH}_{4}\right)_{2} \mathrm{SO}_{4}, 0.96 ; \mathrm{KH}_{2} \mathrm{PO}_{4}, \mathrm{I} \cdot 14 ; \mathrm{Na}_{2} \mathrm{HPO}_{4} \cdot \mathrm{I}_{2} \mathrm{H}_{2} \mathrm{O}, 6 \cdot 13$; carbon source, $4 \cdot 0 ; \mathrm{pH}_{7} \cdot 1$. For chemostat operation the concentration of the rate-limiting nutrient was reduced to give a steady state biomass in the culture vessel of $0.12 \mathrm{mg} d r y \mathrm{wt} / \mathrm{ml}$ over as wide a range of dilution rates as possible. In C-limited conditions this was $400 \mathrm{mg} \mathrm{C}$ source/l; $\mathrm{NH}_{4}^{+}{ }_{-}, \mathrm{K}^{+-}, \mathrm{Mg}^{2+-}, \mathrm{SO}_{4}{ }^{2-}$ - and $\mathrm{PO}_{4}{ }^{3-}$-limiting media contained, respectively, $27 \cdot 3,2 \cdot 0,0.35,1 \cdot 4$ and $10.0 \mathrm{mg}$-ions/1, the concentration of all the other ions being as in the standard medium. Ion concentrations were altered as required by either supplementing the medium with $\mathrm{Na}_{2} \mathrm{SO}_{4}$ or $\mathrm{KCl}$ or replacing sulphates with equimolar amounts of the corresponding chlorides or potassium salts with sodium salts or both. Halving the concentration of the rate-limiting nutrient reduced the biomass to one-half while doubling the former also doubled the latter. Phosphate buffer, $\mathrm{pH} 7 \cdot \mathrm{I}$, contained (g/l): $\mathrm{KH}_{2} \mathrm{PO}_{4}, 2 \cdot 96 ; \mathrm{Na}_{2} \mathrm{HPO}_{4}$. ${ }_{12} \mathrm{H}_{2} \mathrm{O}, \mathrm{I} 6 \cdot 0$. Preliminary experiments showed that $\mathrm{MTG}$ remained stable in this buffer for at least $\mathrm{I} 4$ days at $\mathrm{O}{ }^{\circ} \mathrm{C}$ and that $\beta$-galactosidase synthesis in glucose-limited chemostat culture was independent of the MTG concentration above $1 \mathrm{O}^{-4} \mathrm{M}$.

Enzyme assays. The $\beta$-galactosidase assay was based on the techniques of Lederberg (1950) and Richards \& Hinshelwood (I96I). The bacteria were harvested by centrifugation at $8000 \mathrm{~g}$ for $5 \mathrm{~min}$, washed with phosphate buffer and resuspended in the same buffer at a turbidity corresponding to $0.28 \pm 0.03 \mathrm{mg} \mathrm{dry} \mathrm{wt} / \mathrm{ml}$. This precision was necessary since the $\beta$-galactosidase specific activity of treated preparations, unlike that of intact organisms, varied with the concentration used in the assay mixture. Organisms were shaken with toluene ( 2 drops $/ 5 \mathrm{ml}$ suspension) at $30^{\circ} \mathrm{C}$ for $5 \mathrm{~min}$ or disrupted at $0^{\circ} \mathrm{C}$ for $7 \mathrm{~min}$ in a MSEMullard ultrasonic disintegrator. A $5 \mathrm{ml}$ suspension of intact or treated organisms, incubated at $30{ }^{\circ} \mathrm{C}$, was added to $20 \mathrm{ml} o$-nitrophenyl- $\beta$-D-galactopyranoside (ONPG) solution $\left(2.5 \mathrm{mg} / \mathrm{ml}\right.$ phosphate buffer) shaken at $30^{\circ} \mathrm{C}$. At intervals $5 \mathrm{ml}$ samples were withdrawn, added to $\mathrm{I} \mathrm{ml} \mathrm{M}-\mathrm{Na}_{2} \mathrm{CO}_{3}$ solution and their extinctions read at $420 \mathrm{~nm}$ in a Unicam SP 600 spectrophotometer against a blank withdrawn at zero time. $\alpha$-Galactosidase was similarly determined using $p$-nitrophenyl- $\alpha$-D-galactopyranoside as the chromogenic substrate. $\beta$-Glucosidase was assayed as described by Dean \& Rodgers (1969). Specific activities were obtained from the initial rate of $o$ - (or $p$-) nitrophenol released per unit dry wt of organisms and are expressed as $\mathrm{nmol} \mathrm{min}^{-1} \mathrm{mg}^{-1}$.

\section{RESULTS}

Effect of the dilution rate $(D)$. In agreement with earlier observations on Escherichia coli $\mathrm{K} I 2$ (Lederberg, 1950), Lineweaver-Burk plots of the $\beta$-galactosidase specific activity of Klebsiella aerogenes estimated at a range of substrate (ONPG) concentrations were linear. The slopes of the lines obtained using intact organisms were approximately 40 times less 


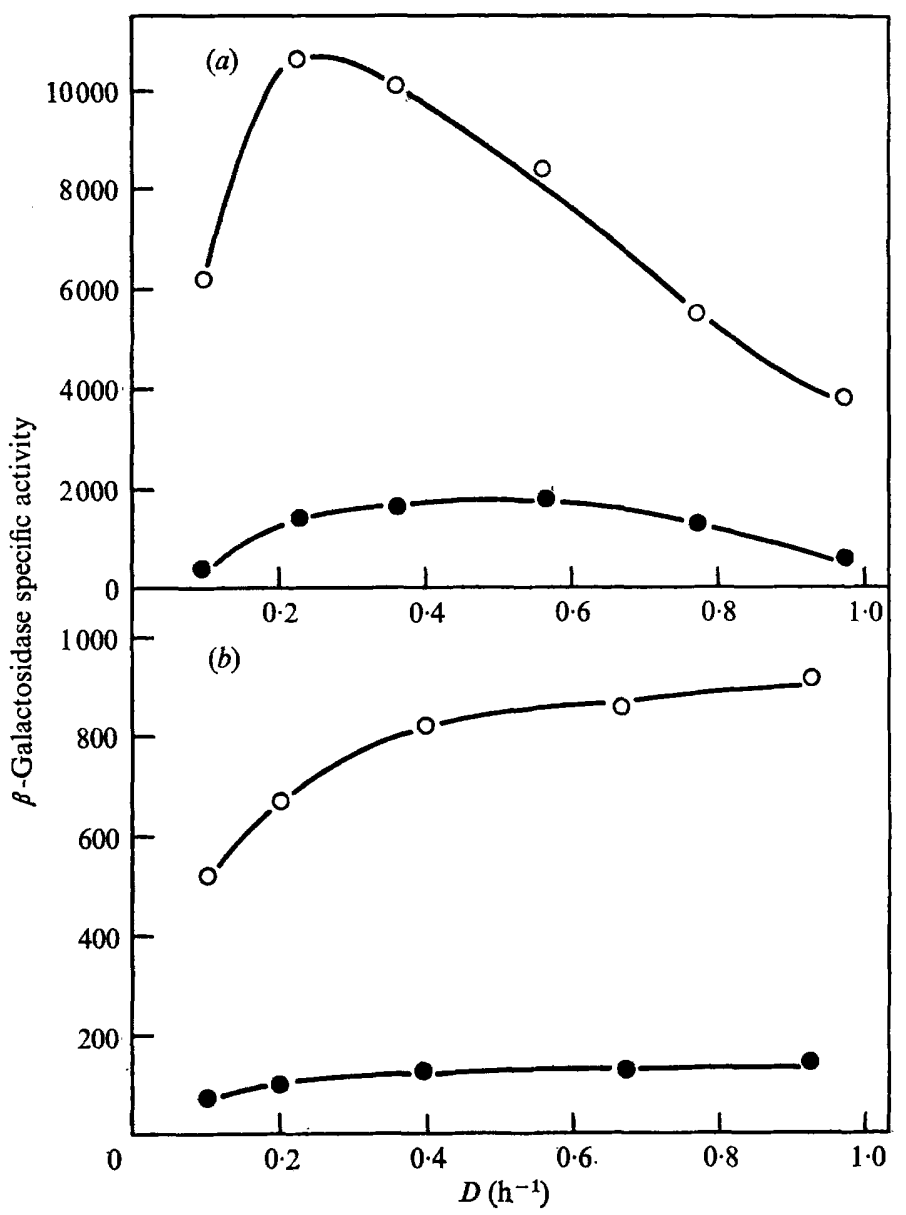

Fig. I. Effect of the dilution rate $(D)$ on the steady state levels of $\beta$-galactosidase specific activity of bacteria grown in $(a)$ lactose-limited and $(b) \mathrm{K}^{+}$-limited medium. $\bigcirc$, Treated organisms; $O$, intact organisms.

than with disrupted bacteria. This is consistent with the intact organism activity being a measure of a rate-limiting transport step while the activity of treated organisms estimates the total enzyme present (Lederberg, 1950; Monod, Pappenheimer \& Cohen-Bazire, 1952; Herzenberg, $1959 ; \mathrm{Koch}, 1963,1964)$. Formaldehyde (0.25 M), a strong inhibitor of permeases (Koch, 1964), rapidly decreased the activity of intact organisms but had a negligible effect on that of treated preparations. The steady state levels of $\beta$-galactosidase specific activity in bacteria grown for a long time in lactose-limited chemostats passed through a sharp maximum at $D=0.20$ to $0.25 \mathrm{~h}^{-1}$ but substrate transport was less affected by changes in $D$ (Fig. I $a$ ). In $\mathrm{K}^{+}$-limited conditions with lactose as the carbon source the specific activity of the organisms increased with increasing $D$ (Fig. I $b$ ) but substrate transport was again less affected. Essentially similar results were obtained in $\mathrm{NH}_{4}{ }_{-}, \mathrm{Mg}^{2+}, \mathrm{SO}_{4}{ }^{2-}$ - and $\mathrm{PO}_{4}{ }^{3-}$ limited systems, although the specific activities were less at all dilution rates than in $\mathrm{K}^{+-}$ limitation. The variations were much less than that due to the change from $\mathrm{C}$-limitation to limitation by any other nutrient in the medium; e.g. at $D=0.25 \mathrm{~h}^{-1}$ the $\beta$-galactosidase specific activity of bacteria using lactose as sole carbon source was 10750 units in C-limited 


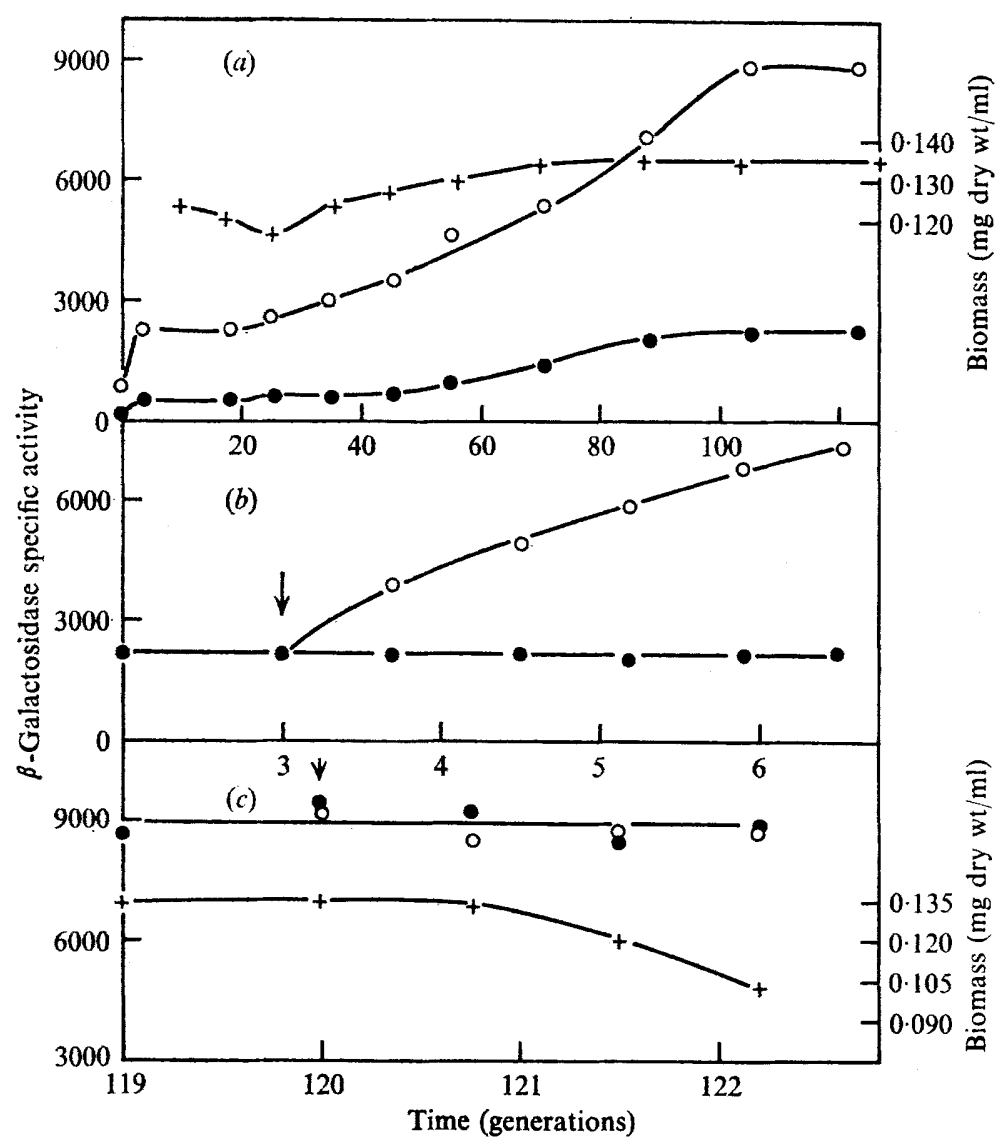

Fig. 2. (a) Development of $\beta$-galactosidase hyperactivity. $\bigcirc$, Treated organism activity; $\bullet$, intact organism activity; +, biomass. $(b),(c)$ Effect of adding MTG $\left(5 \times 10^{-4} \mathrm{M}\right)$ to the culture at the quasi and the final steady states of growth respectively. $\downarrow$, Addition of MTG; $\bigcirc$, enzyme activity in presence of MTG; 0 , enzyme activity in control; + , biomass. In $(b)$ the biomass remained constant at the initial level. $D=0.5 \mathrm{~h}^{-1}$.

conditions compared to $450,718,554,470$ and 492 units in $\mathrm{NH}_{4}^{+-}, \mathrm{K}_{-}^{+}, \mathrm{Mg}^{2+-}, \mathrm{SO}_{4}^{2--}$ or $\mathrm{PO}_{4}{ }^{3-}$-limited conditions respectively. The major factor determining the $\beta$-galactosidase activity is the relative concentration of lactose in the medium. The plots of biomass against $D$ conformed to the standard patterns reported earlier for these nutrient-limited conditions (Dean \& Rogers, 1967; Tempest \& Dicks, 1967).

Quasi steady states: hyperactivity. Following the change-over from batch culture to continuous culture in lactose-limited medium, about 100 generations were necessary before the $\beta$-galactosidase specific activity reached its maximum level even though the organisms had been previously conditioned to lactose (Fig. 2a). At the start of chemostat operation the specific activity rose rapidly and soon settled at a quasi steady state level which persisted for about 15 generations, after which it increased gradually to the final level. This experiment has been repeated twice at the standard population density and once at one half of this value with very similar results.

Adding MTG $\left(5 \times 10^{-4} \mathrm{M}\right)$ to the medium feed at the final stage had no effect on specific 


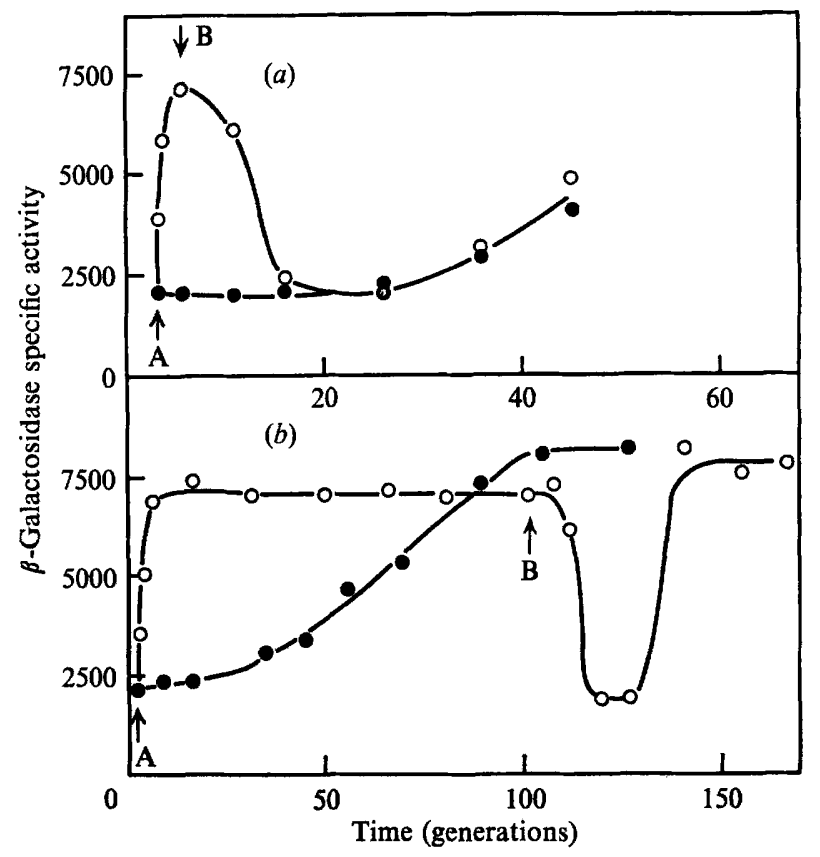

Fig. 3. Effect of MTG-removal on induced hyperactivity. Addition of MTG started at A and its dilution out at B. O, Enzyme activity in MTG-induced organisms; O, enzyme activity in control. $D=0.5 \mathrm{~h}^{-1}$.

activity but the biomass diminished (Fig. 2c). MTG addition during the quasi steady state led to a rapid increase in specific activity to the level obtained by long-continued chemostat culture (Fig. 2b). However, this MTG-induced activity declined rapidly on removing MTG from the lactose medium even when many generations of growth had taken place in its presence (Fig. 3).

Hyperactivity only developed in lactose-limited chemostats. The much lower specific activities obtained after Io to 20 generations in any of the other nutrient-limited chemostats or in the turbidostat were not increased during prolonged culture. Similarly, in lactoselimited batch culture, the behaviour after 200 and 300 daily subcultures was not significantly different, the $\beta$-galactosidase specific activity reaching its maximum level of about I000 units as lactose exhaustion terminated growth. Prolongation of the stationary phase led to a decline in activity in which transport processes, as measured by the specific activity of intact organisms, were more affected that the total $\beta$-galactosidase specific activity. For example, at the beginning of the stationary phase and 24 and $55 \mathrm{~h}$ later the ratio $(R)$ of the specific activity of treated bacteria $(T)$ to that of intact bacteria $(I)$ was $5 \cdot 0,7 \cdot 2$ and $12 \cdot 8$, the values of $T$ being 1025, 920 and 740 units respectively. With Escherichia coli Cohen \& Monod (1957) obtained values of $R$ between I5 and 20, whereas in actively growing $K$. aerogenes it was generally in the range 3 to 10 , the value depending on the experimental conditions. Some examples are given in Table $\mathbf{I}$.

Mixed carbon substrates. Adding glucose to the medium supplied to a lactose-limited chemostat culture in the quasi steady state led to a rapid increase in biomass showing that the second carbon substrate was also being metabolized. Simultaneously, the $\beta$-galactosidase specific activity of the bacteria dropped to about one half of its original level, and diminished 


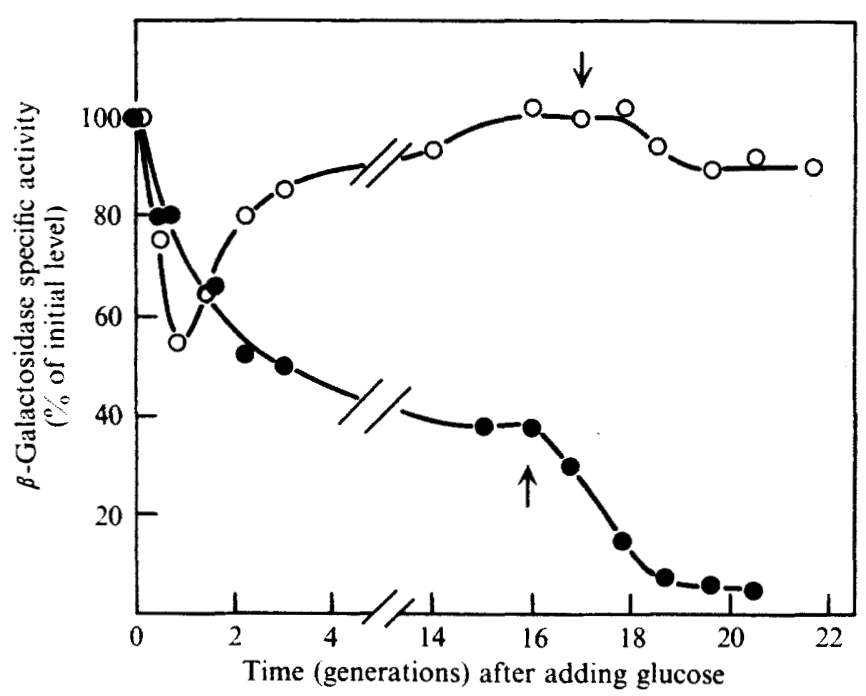

Fig. 4. Effect of adding glucose (200 mg/l) to the medium supply of a lactose-limited chemostat (200 $\mathrm{mg} / 1$ lactose) at the quasi $(O)$ and the final $(O)$ steady states respectively. At the stages indicated by the arrows the medium supply was further changed to one containing glucose $(400 \mathrm{mg} / \mathrm{l})$ as the sole carbon source. $D=0.5 \mathrm{~h}^{-1}$.

Table $\mathrm{I}$. The ratio $R$ for bacteria grown in various environments

\begin{tabular}{|c|c|c|c|c|}
\hline \multirow[b]{2}{*}{ Growth conditions } & \multicolumn{4}{|c|}{$\beta$-Galactosidase specific activity } \\
\hline & $\underset{\left(\mathrm{h}^{-1}\right)}{D}$ & $\begin{array}{c}\text { Intact } \\
\text { bacteria }(I)\end{array}$ & $\begin{array}{c}\text { Treated } \\
\text { bacteria }(T)\end{array}$ & $R=T / I$ \\
\hline ted batch culture, logarithm phase & - & 170 & 850 & $5 \cdot 0$ \\
\hline ed chemostat & 0.25 & 1,500 & 10,750 & $7 \cdot 2$ \\
\hline ited chemostat, & 0.25 & 164 & 1,640 & $10 \cdot 0$ \\
\hline aducer & 0.75 & 130 & 574 & $4 \cdot 4$ \\
\hline d (lactose) chemostat & 1.00 & 199 & 655 & $3 \cdot 3$ \\
\hline $\begin{array}{l}\text { d (glycerol) chemostat, } \\
\text { nducer }\end{array}$ & $0 \cdot 10$ & 171 & 1,196 & $7 \cdot 0$ \\
\hline idostat & $1 \cdot 25$ & 205 & $\mathbf{I}, \mathbf{1 7 0}$ & $5 \cdot 7$ \\
\hline
\end{tabular}

rapidly when glucose became the sole carbon source (Fig. 4). In sharp contrast, apart from an initial drop followed by a rapid recovery, the specific activity of bacteria exhibiting hyperactivity was unaffected by their simultaneous utilization of lactose and glucose and only slightly decreased when glucose provided the carbon for growth (Fig. 4). Other carbon compounds (at $200 \mathrm{mg} / \mathrm{l}$ ) were similarly tested. Galactose or glucose-6-phosphate addition produced very similar responses to glucose addition, although the transient repression of the hyperactivity was less pronounced. Maltose had a more marked effect, about 25 generations elapsing before the normal level of hyperactivity was restored and during this period the biomass gradully increased. Citrate, which was rapidly metabolized, and $\alpha$-methylglucoside and 2-deoxyglucose, which were not utilized, were without effect.

Before use in the experiments already described, bacteria received at least 100 daily subcultures in medium containing lactose as the sole carbon source. Bacteria not previously exposed to lactose exhibited in batch culture a diauxic lag of $10 \mathrm{~h}$ before the lactose in glucose + lactose medium was attacked. In C-limited chemostat culture both carbon sources 


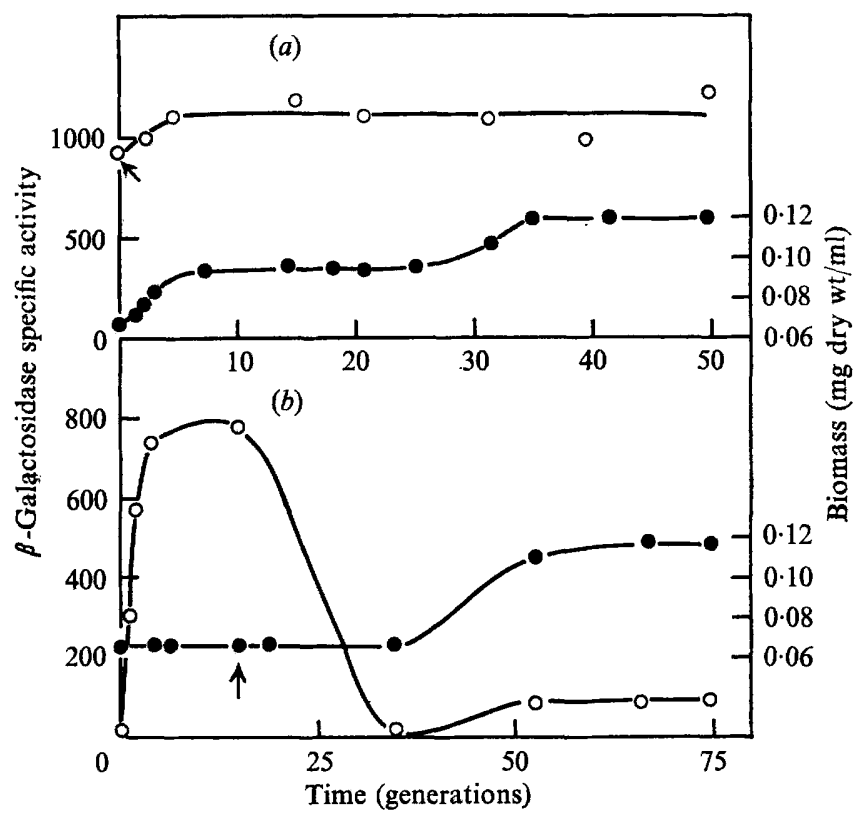

Fig. 5. Elimination by MTG of diauxic lags in chemostat culture. Bacteria not previously exposed to lactose were grown in glucose-limited medium $\left(200 \mathrm{mg} / \mathrm{l}\right.$ glucose) containing MTG $\left(5 \times 10^{-4} \mathrm{M}\right)$ until a steady state was reached. At the time shown by the arrows lactose $(200 \mathrm{mg} / \mathrm{l})$ was added to the medium supply. In (a) MTG was present throughout the experiment but in $(b)$ its addition was stopped at the time of lactose addition, $D=0.5 \mathrm{~h}^{-1} .0, \beta$-Galactosidase specific activity;, biomass.

\section{Table 2. Utilization of lactose by glucose-adapted cells}

Lactose (200 mg/l) was added to the input medium of chemostat cultures of glucose-adapted cells in the steady state of growth in glucose-limited medium. The total sugar concentration was $400 \mathrm{mg} / 1$ which is C-limiting.

\begin{tabular}{|c|c|c|c|}
\hline \multicolumn{2}{|c|}{ Lag before lactose was attacked } & \multicolumn{2}{|c|}{ Length of transition phase } \\
\hline $\mathbf{h}$ & Generations & h & Generations \\
\hline 10 & - & 一 & - \\
\hline 16 & $5 \cdot 8$ & $2 \mathbf{I}$ & $7 \cdot 6$ \\
\hline $\begin{array}{l}31 \\
64 \\
84\end{array}$ & $\begin{array}{r}21.4 \\
66.6\end{array}$ & $\begin{array}{l}28 \\
60 \\
03\end{array}$ & $\begin{array}{r}19.3 \\
62.5 \\
26.0\end{array}$ \\
\hline 84 & II3.0 & 93 & 126.0 \\
\hline
\end{tabular}

* Batch culture, diauxic lag $10 \mathrm{~h}$.

were eventually used but the higher the dilution rate the longer the interval, both in generations and in hours, before the lactose was metabolized (Table 2). Thereafter, the biomass and the $\beta$-galactosidase specific activity gradually increased through a transition phase, which was also longer the higher the dilution rate, and then settled at levels which remained constant until the experiments were terminated 50 to 100 generations later. Similar changes in biomass were observed by Baidya, Webb \& Lilly (I967) who did not measure enzyme activities. The final specific activities were very low, values of $63,64,76$ and 62 units, respectively, being obtained at $D=0.25,0.48,0.72$ and $0.94 \mathrm{~h}^{-1}$. In a parallel experiment at $D=0.5 \mathrm{~h}^{-1} \mathrm{using}$ lactose alone as the carbon source, the $\beta$-galactosidase specific activity was 205 units when a similar amount of growth had taken place. 
Glucose-adapted bacteria, incubated with MTG, readily metabolized added lactose, provided that the $\beta$-galactosidase level was maintained by continued MTG addition (Fig. 5). Burstein, Cohn, Kepes \& Monod (1965) claimed that the inducer of $\beta$-galactosidase is not lactose but is produced from it by the enzyme. On this basis it might be expected that, in this experiment, the high $\beta$-galactosidase level would transform the added lactose into active inducer. However, following MTG removal, the enzyme activity fell to the basal level before being ultimately re-induced by lactose (Fig. $5 b$ ).

$\alpha$-Galactosidase and $\beta$-glucosidase. $\alpha$-Galactosidase hyperactivity also resulted from protracted chemostat culture in C-limited conditions with melibiose (Gal-p $\alpha 1 \rightarrow 6-\mathrm{Glc}$ ) as the inducer and sole carbon source; a steady state specific activity of 4900 units was obtained. As with $\beta$-galactosidase, hyperactivity was associated with more efficient utilization of the carbon substrate, but the quasi steady state was more prolonged and persisted for 25 generations at $D=0.5 \mathrm{~h}^{-1}$. Protracted growth in cellobiose (Glc $\mathrm{p} \beta 1 \rightarrow 4 \mathrm{Glc}$ )-limited chemostat culture did not lead to $\beta$-glucosidase hyperactivity, the specific activity of 48 units after 20 generations remaining unchanged throughout a further 100 generations. In both these examples, as in the lactose experiments, the bacteria were preconditioned to the new carbon sources by serial subculture.

\section{DISCUSSION}

A striking feature of these results is the need to precondition Klebsiella aerogenes NCIB 4I 8 to lactose by many serial subcultures in batch culture to obtain $\beta$-galactosidase hyperactivity in lactose-limited chemostat culture within a short time. Although various workers (e.g. Horiuchi, Tomizawa \& Novick, 1962; Silver \& Mateles, 1969; Vojtisek, Sikyta \& Slezak, 1969) have obtained strains of Escherichia coli exhibiting hyperactivity, the need, if any, for preconditioning has not been pointed out. The low activities found in our experiments when organisms, which had never been exposed to lactose were grown in C-limited chemostats containing either lactose or glucose and lactose, remained constant over a time during which hyperactivity would have developed using lactose-conditioned cells. The mixed substrate method should have facilitated the selection of any existing hyperactive variants (Silver \& Mateles, 1969) and yet the activity was higher when lactose alone was the carbon source. Whether chemostat culture would ever lead to hyperactivity is not known but, if so, the process must be very protracted. Daily batch subculture leads to a more rapid increase in activity both in lactose-limited conditions and also when excess lactose is present (Richards \& Hinshelwood, 1961), which suggests that sojourn in the stationary phase of the growth cycle facilitates lactose conditioning. Hyperactivity is not, however, obtained.

Horiuchi et al. (1962) have explained, in terms of 'Monod saturation curves', how variants possessing augmented $\beta$-galactosidase activity and thereby capable of using lactose more efficiently than normal organisms at very low substrate concentrations, would have a selective advantage. Carbon-limited chemostat culture provides precisely these conditions and the increase in biomass in the final stage of our lactose-limited experiments accords with an increased utilization of the carbon substrate. However, in the preceding quasi steady state (Fig. 2) the culture was rapidly inducible with MTG to the hyperactive level without any fall in biomass, which suggests that most of the organisms in the culture participate, and argues against MTG acting as a selective agent by only allowing hyperactive variants to multiply. Moreover, MTG proved to be growth inhibiting at the final (hyperactive) stage, but not before, and on the whole it seems unnecessary to postulate, as Novick \& Horiuchi (I96I) did for Escherichia coli, that hyperactive cells are mutants containing extra copies of the 'lactose' gene. Horiuchi et al. (1962) found no corresponding increase in $\beta$-galactoside permease 
activity in their hyperactive strain although, at low substrate concentrations, the rate of transport, rather than the rate of hydrolysis, controls the rate of lactose utilization. They measured the rate of uptake of labelled non-metabolizable substrate, however, which Koch (I963) considers less meaningful than estimates based on the rate of hydrolysis of ONPG by intact cells. Using the latter criterion, we found that the rate of substrate transport and the total $\beta$-galactosidase specific activity increased approximately in parallel during the progression from batch culture to the final steady state.

The failure to induce hyperactive cells further with MTG suggested that the maximum activity possible had been reached. Nevertheless, the actual level varied with the dilution rate and passed through a relatively sharp maximum value at $D=0.25 \mathrm{~h}^{-1}$. Dilution rate responses of this sort are not uncommon among the various patterns which have been observed in chemostat culture; this topic has been discussed in some detail by Dean (I971).

The low $\beta$-galactosidase specific activities observed when bacteria not preconditioned to lactose were exposed to a mixture of glucose and lactose in C-limited conditions were very much less dependent on dilution rate. In such circumstances the onset of lactose utilization clearly depends on the occurrence of a certain critical level of $\beta$-galactosidase within the bacteria. Such bacteria may then divide, in which case their progeny will have similar enzyme levels, or they may be washed out of the culture vessel before dividing. The former speeds adaptation to lactose, the latter delays it; the ratio of the two processes and the time taken for the formation of the enzyme determine the time elapsing before the glucose and lactose are simultaneously utilized at the maximum rate. The development of the ability to utilize lactose frees the organisms from the restrictions imposed by glucose limitation so that their specific growth rate can increase from $D$ to $(D+X)$, where $X$ is the increment due to lactose hydrolysis (Dean, 197I). It then follows that any lactose-utilizing organisms should outgrow the rest at a rate proportional to $(D+X) / D$ which increases as $D$ decreases (Table 2). Silver \& Mateles (1969) ascribed the development of $\beta$-galactosidase in similar circumstances in cultures of Escherichia coli $6 \mathrm{~B}$ to a selection of constitutive mutants, but we found no evidence of a constitutive $\beta$-galactosidase when our glucose-conditioned bacteria used glucose and lactose simultaneously. The history of their strain is not given, however, and, apart from the final state being more rapidly reached, its behaviour was similar to that shown by our lactoseconditioned cells in lactose-limited medium (Fig. 2).

Mandelstam (1962) and Clark \& Marr (1964) have shown that the rate-limiting addition of the carbon source to a culture restricts the rate of catabolism relative to the rate of anabolism, leading to minimum catabolite repression, while the converse results from the rate-limiting addition of other nutrients. Much lower enzyme activities would then be expected in cultures that were not carbon-limited than in those that were, and have been demonstrated in the experiments reported earlier. Nevertheless, these low activities increased with increasing $D$, which suggests that the degree of repression is less at high growth rates. The reason for this is not known but might emerge from a determination of the intracellular concentrations of 'critical' metabolites.

The elimination of diauxic lags during batch culture in glucose + lactose medium, when a high $\beta$-galactosidase activity is maintained by the presence of a non-metabolizable inducer, has been demonstrated (e.g. Loomis \& Magasanik, 1967). Our results show that it also occurs in chemostat culture but the lactose is utilized in two stages. It seems unlikely that the stepwise increase in biomass (Fig. $5 a$ ) is due to an initial inability to utilize galactose, since in a control experiment added galactose was immediately rapidly metabolized, or to an increased efficiency of lactose hydrolysis, since no increase in $\beta$-galactosidase specific activity was observed. However, following the induction of the enzymes necessary in a new environment, 
some time can elapse before the cellular economy reaches its optimum efficiency (Dean \& Hinshelwood, 1966) and in this connexion it is of interest that the increase in biomass occurred after about 25 generations. This is similar to the delay before lactose was attacked in the corresponding experiment in which MTG was absent (Table 2) which suggests that it represents the minimum time necessary.

We thank the Medical Research Council for providing a scholarship for training in research methods for $R$. W. S.

\section{REFERENCES}

BaidyA, T. K. N., WeBB, F. C. \& Lilly, M. D. (1967). The utilization of mixed sugars in continuous fermentation. I. Biotechnology and Bioengineering 9, 195-204.

Burstein, C., Cohn, M., Kepes, A. \& Monod, J. (I965). Rôle du lactose et de ses produits metaboliques dans l'induction de l'opéron lactose chez Escherichia coli. Biochimica et biophysica acta 95, 634-639.

Clark, D. J. \& MARr, A. G. (1964). Studies on the repression of $\beta$-galactosidase in Escherichia coli. Biochimica et biophysica acta $92,85-98$.

Cohen, G. N. \& Monod, J. (1957). Bacterial permeases. Bacteriological Reviews 21, I69-194.

DeAN, A. C. R. (1972). In Environmental Control of Cell Synthesis and Function, pp. 245-259. Edited by A. R. C. Dean, S. J. Pirt, \& D. W. Tempest. London and New York: Academic Press.

DeAN, A. C. R. \& Hinshelwood, C. (1966). Growth, Function and Regulation in Bacterial Cells, pp. 103-I35, 260-284. Oxford: Clarendon Press.

DeAN, A. C. R. \& Rodgers, P. J. (1969). Steady state levels of dehydrogenases and $\alpha$ - and $\beta$-glucosidases in Klebsiella aerogenes. Journal of General Microbiology 57, I69-I 78.

DeAn, A. C. R. \& Rogers, P. L. (1967). The cell size and macromolecular composition of Aerobacter aerogenes in various sysțems of continuous culture. Biochimica et biophysica acta 148, 267-279.

Harrison, D. E. F. \& PirT, S. J. (I965). Oxygen tension and glucose metabolism of Klebsiella aerogenes. Journal of General Microbiology 4r, ix-x.

Herzenberg, L. A. (1959). Studies on the induction of $\beta$-galactosidase in a cryptic strain of Escherichia coli. Biochimica et biophysica acta 31, 525-538.

Horiuchi, T., TOMIZAWA, J. \& Novick, A. (1962). Isolation and properties of bacteria capable of high rates of $\beta$-galactosidase synthesis. Biochimica et biophysica acta 55, I52-163.

JACOB, F. \& MoNoD, J. (1961). On the regulation of gene activity. Cold Spring Harbor Symposia on Quantitative Biology 26, 193-209.

KocH, A. L. (1963). The inactivation of the transport mechanism for $\beta$-galactosides of Escherichia coli under various physiological conditions. Annals of the New York Academy of Sciences 102, 602-620.

Косн, A. L. (1964). The role of permease in transport. Biochimica et biophysica acta 79, 177-200.

LEDERBERG, J. (1950). The $\beta$-D-galactosidase of Escherichia coli strain $\mathrm{K}$ 12. Journal of Bacteriology 60, 381392.

LoOMIs, W. F. \& MAGASANIK, B. (1967). Glucose-lactose diauxie in Escherichia coli. Journal of Bacteriology 93, $1397-1401$.

MANDELSTAM, J. (1962). The repression of constitutive $\beta$-galactosidase in Escherichia coli by glucose and other carbon sources. Biochemical Journal 82, 489-493.

Monod, J. \& CoHN, M. (I952). La biosynthèse induite des enzymes (adaptation enzymatique). Advances in Enzymology 13, 67-119.

Monod, J., Pappenheimer, A. M. \& Cohen-Bazire, G. (1952). La cinétique de la biosynthèse de la $\beta$ galactosidase chez $E$. coli considérée comme fonction de la croissance. Biochimica et biophysica acta 9, 648-660.

Novick, A. \& Horiuchi, T. (1961). Hyper production of $\beta$-galactosidase by Escherichia coli bacteria. Cold Spring Harbor Symposia on Quantitative Biology 26, 239-245.

Pardee, A. B. \& Prestidge, L. S. (196r). The initial kinetics of enzyme induction. Biochimica et biophysica acta $49,77-88$.

RICHARDS, N. (1969). Regulation of gratuitous $\beta$-galactosidase synthesis in Aerobacter aerogenes during an adaptive process. Journal of General Microbiology 55, 361-370.

Richards, N. \& HinsheLwOOD, C. (I96I). Observations on the $\beta$-galactosidase activity of Bacterium lactis aerogenes (Aerobacter aerogenes). Proceedings of the Royal Society B 154, 463-477. 
Richards, N. \& HinsheLwood, C. (1962). Stabilization of $\beta$-galactosidase in Bacterium lactis aerogenes. Proceedings of the Royal Society B 156, 20-40.

StLver, R. S. \& MATELES, R. I. (1969). Control of mixed-substrate utilization in continuous cultures of Escherichia coli. Journal of Bacteriology 97, 535-543.

Strange, R. E. (1961). Induced enzyme synthesis in aqueous suspensions of stationary phase Aerobacter aerogenes. Nature, London 191, $1272-1274$.

TemPest, D. W. \& Dicks, J. W. (1967). In Microbial Physiology and Continuous Culture, pp. 140-153. Edited by E. O. Powell, C. G. T. Evans, R. E. Strange \& D. W. Tempest. London: Her Majesty's Stationery Office.

VoJTISEK, V., SiKYTA, B. C. \& SLeZAK, J. (1969). Regulation of the hyper production of $\beta$-galactosidase in continuous culture of Escherichia coli B. In Continuous Cultivation of Micro-organisms, pp. 215-223. Edited by I. Málek, K. Beran, Z. Fencl, V. Munk, J. Řičica \& H. Smrčkova. Prague: Academia; London: Academic Press. 